income and relied upon the modest payment she received working as a 'fulltimer' for successive campaigning organisations. She and Ben Elmy could not afford a 'live-in' servant, and instead employed local women to undertake the heaviest and most unpleasant household tasks, while the rest of the housekeeping and childcare fell to Wolstenholme Elmy. 'Her working day (domestic and administrative) could be as long as fourteen hours' and the effects were felt on both her health and her temper (p. I06).

Political dedication and clarity of vision could also manifest itself as selfregard and an autocratic mode of organising. As this biography rather more politely suggests, Wolstenholme Elmy was 'a determined workaholic, who did not always toil with devoted collegiality' (p. I24). Wright's evident fondness for Wolstenholme Elmy does not prevent her from acknowledging these less than ideal aspects of her subject's personality. It might have been interesting, nonetheless, to pursue this line of inquiry a little further. In a world in which women are still required to combine intellectual and political acumen with a level of social skills rarely expected of men, perhaps a crotchety, difficult, driven and single-minded fighter on behalf of a collective cause might be a particularly interesting kind of 'heroine' to have.

LAURA SCHWARTZ

doi:IO.I093/ehr/ceu364

University of Warwick

\title{
Magic Lantern Empire: Colonialism and Society in Germany, by John Phillip
} Short (Ithaca, NY: Cornell U.P., 20I2; pp. 232. \$39.95).

John Phillip Short's book examines German colonialism 'in its metropolitan context' (p. 3), and focuses specifically on the interactions between colonial associations, the Social Democratic Party (SPD), and the working class. $\mathrm{He}$ draws upon early, well-known and meticulous studies by Hans-Ulrich Wehler and Klaus J. Bade, and supplements these with a postcolonial interest in visual and mass cultural representations, together with a strong emphasis on discourse analysis.

Short first considers the well-known organised colonial movements. The rhetoric of the bourgeois so-called 'national leagues' declared colonialism to be a solution for a vast range of social problems inherent in a nation in a dynamic transition from an agrarian society to urban and industrial modernity. In the I89os, colonial propaganda shifted from taking the working classes as its object of concern and instead began to address them directly in order to overcome a certain weariness with empire that had set in after initial enthusiasm, and in order to get broader support for the colonial project. The working classes were able to experience empire through panoramas and exhibitions, as well as ethnographic and travelling shows. These shows, combining propaganda, distraction, education and commerce, were also frequented by the educated elite and thus evolved into places where class divides became permeable. Similarly, colonial literature blending geographical and ethnographical information with elements of cheap novels attracted the working class in a 'dialectic of science and enchantment'. 
Short interprets colonial propaganda in the context of class conflict, endeavouring to trace concrete responses of the working class to bourgeois propaganda and popular entertainment. Ticket sales for colonial shows and reading lists of the most-read books in socialist libraries may provide some sort of quantitative notion of the reception of 'colonial knowledge' by the working class, but not much information about its impact on mentalities. However, such material proves the fascination of the working class for colonial fantasies and exoticism during the continued rejection of imperialism by the SPD. Short has also found more evidence for working-class colonial knowledge and reflection in various letters to the German Colonial Society. Most of them applied for financial support for proposed emigration to a German protectorate, sometimes adapting arguments borrowed from colonial propaganda to make their case.

With the 'Hottentot' Election, Short again turns to a very well-researched topic of German colonial historiography. These elections were fought largely over the issue of Germany's war against the Herero in South-West Africa and, in the end, strengthened the position of the nationalist pro-governmental parties. Short indicates that, while the SPD leadership started to embrace the pre-colonial line of the governmental bloc parties, the working class and SPD voters were more resistant to the nationalist fervour of empire.

Short's study draws broadly on periodicals and newspapers and rehearses many familiar facts. It is perhaps less than fully up-to-date with recent trends in scholarship on the social, economic and political history of Imperial Germany during modernisation and industrialisation. But Short sheds some new light on the colonial knowledge of the subaltern readers and the working class, not least because he includes archival sources for this specific purpose. He offers the intriguing argument that German colonial propaganda operated as a form of knowledge that both reproduced and dissolved class boundaries, and that it was out of this conflict that a modern image of the global emerged in Germany at the beginning of the twentieth century. The study offers a very readable overview and a good synthesis of the early metropolitanfocused research into colonial history with the postcolonial studies of the last twenty years.

\section{Conservatism for the Democratic Age: Conservative Cultures and the Challenge of Mass Politics in Early Twentieth Century England, by David Thackeray (Manchester: Manchester U.P., 20I3; pp. 220. £65).}

David Thackeray has written an important and original book which investigates how the Conservative Party evolved and adapted its organisational culture, image and popular appeal in an age of profound political flux and uncertainty. His aim is to explain why a party which appeared to be in real trouble after its debacle in the 1906 election and the twin stalemates of I9Io rose to meet the challenges of post-war society and universal suffrage, and emerged as the dominant force of inter-war politics under Stanley Baldwin. Instead of 